Apart from this brittleness problem, two other problems appear when beryllium is used in a reactor. In the carbon dioxide-water coolant mixtures, breakaway, that is, accelerating, oxidation can occur. The papers at the conference did not add a great deal on this topic, although the Australian Atomic Energy Commission reported an inhibition of breakaway by oxidation of the beryllium powder at $800^{\circ} \mathrm{C}$. in oxygen prior to sintering. Irradiation damage also occurs in a reactor. The normal displacement of atoms by neutrons that is responsible for the damage in steel and copper has little effect in beryllium, and damage only appears at doses above about $10^{19}$ neutrons $\mathrm{cm} .^{-2}$ when it is due to the helium generated by neutron reaction with beryllium. R. S. Barnes and others have shown that when present as small bubbles the helium leads to hardening and loss of ductility. Larger bubbles accumulate at the grain boundaries and these promote fracture in creep. They can also give grain boundary permeability, which is, of course, highly undesirable in a fuel can.

It is perhaps clear that there is no lack of beryllium problems. However, considering the advances that have been achieved in the quite short period of really active interest, the future is not without hope.

N. J. Ретсн

\title{
CHANGES OF CLIMATE
}

A S was entirely appropriate for a symposium sponsored by the Unesco major project on scientific research in arid lands, an effort was made on the occasion of the recent meeting in Rome (October 2-7), arranged by Unesco and the World Meteorological Organization, to restrict the interest to climatic variations which have occurred since the latest glaciation, with particular attention to the period of the meteorological record. The reison behind this decision was no doubt the wish to talk about something which might conceivably have relevance to the nature and trends of the arid lands of to-day-relevance on the scale of economic planning, say, for a hundred years. At the same time this emphasis on what, after all, is micrometric on the geological scale served the purpose of almost eliminat. ing the endless speculations on the causes of ancient climatic change, fascinating though they undoubtedly are. Most geological, geophysical and astronomical happenings which are potential climatic controls, such as mountain building and denudation, drifting of the continents, changes in solar constant and a score of other possible processes, are eliminated when the time-scale is a mere 100 or 1,000 years

It should not be supposed, of course, that examination of such recent changes will throw much light on events on the longer time-scale. The odds are that variability on each different scale of time presents an essentially different problem with an essentially different theoretical explanation. But it is good to keep a symposium within bounds, and the short-period problem is the most tangible, the most suitable for the attention of the theoretical meteorologist, and the most important economically.

More than forty papers were presented, divided into four sessions each of one day and treating respectively the period of the meteorological record (chairman, R. G. Veryard), the late geological and early historical period (chairman, K. W. Butzer), theories of recent climatic change (chairman, R. C. Sutcliffe) and significence of changes of climate (chairman, R. O. Whyte). A summing-up by C. C. Wallén on the last day was particularly well received.

The first session was much helped by the chairman's fine survey of the literature, and the papers presented did not seem to take us very much further with the facts, although substantiating the main features now becoming generally familiar, in particular the warm. ing of extratropical latitudes over the century ending about 1940. J. M. Mitchell's world-wide view of the evidence will be found particularly useful, most of the other contributions being local studies. An effort was made to give attention to the statistical treatment of time series on the basis of a paper by $R$. Sneyers, it being well known that a good proportion of the published literature on climatic change suffers from uncritical and undefined statistical standerds. The general technique of power spectrum anelysis received mention but was not pursued. It was, however, evident that those in the field were very conscious of the problems.

The second session fell mostly to the non-meteorological disciplines, geology, geomorphology, archæology and dendrochronology being represented. Apart from the chairman's valuable introduction, the most persuasive paper was by $\mathrm{R}$. W. Fajrbridge on mean sea-level during the past 20,000 years. It is remarkable and a little puzzling that such clear evidence should be obtainable from data which one would have thought to be confusing.

Under the heading of "Theories of Changes of Climate", the papers were entirely by meteorologists, some of whom were new to the field. This was a good feature, as a weakness of the subject is its failure to attract expert meteorologists aware of the complex behaviour of the atmosphere. The chairman directed attention to the possibilities of variability through feed-back contained within the Earth-ocean system without necessarily recruiting the aid of extraneous factors, radiation, dust, carbon dioxide and the like, and other papers developed the theme: both $J$. Bjerknes and J. Namias were on this side. On the other hand, the most substantial paper was perhaps that by E. B. Kraus, giving the results of a heavy calculation nobly carried out on the effects of a radiation change on the general circulation. The paper was more an illustration of the mathematical approach than a practical solution, but was important as being one of very few attempts that have yet been published.

In the final session, L. P. Smith's paper on "The Significance of Climate Variations in Britain" was very much to the point, and anyone who previously had doubted whether the subject had any economic significance must have given way at this point.

The broad impression created by the meeting is that, for the period of the instrumental record, the subject, which has got to a certain descriptive stage by pure empiricism, is in danger of languishing for want of ideas. Perhaps the symposium marks a turning point, and the attention which climatologists are giving to statistical techniques and which theoretical meteorologists are giving to the general circulation are pointers to the future. For the longer record 
the interest must continue to rest on techniques of exploration and interpretation of evidence, and here there is no slackening of interest, for most of the Earth's surface is almost unexplored.

The facilities provided by the Food and Agriculture Organization and the Italian authorities were admirable. After several experiences of large meetings, one looks forward to those where headphones and simultaneous translations are provided. To be able always to hear is a wonderful asset, even if the language presents no difficulty. It is understood that the complete papers are to be published by Unesco and this will be worth while. A good proportion of the material had been heard or read before, but there would be no sense in insisting on complete novelty for an interdisciplinary meeting where the object is to exchange ideas, not to be mutually iricomprehensible.

R. C. SUTCLIFFE

\section{CHEMICAL WARFARE ON PLANT PESTS AND DISEASES}

T HE first British Insecticide and Fungicide Conference organized by the Association of British Manufacturers of Agricultural Chemicals was held at Brighton during November 7-9 under the presidency of Dr. H. G. Sanders, chief scientific adviser (agriculture) to the Ministry of Agriculture, Fisheries and Food. It was truly an international gathering, for of the 470 delegates attending from official research stations, Government departments and manufacturing firms, nearly one-quarter came from fourteen countries overseas.

The conference consisted of ten successive sessions devoted to important present-day problems in plant pathology and their possible solution by chemical means. During the first two days each session began with one or more introductory papers by authorities on the subject under discussion, and these were followed by brief reports of relevant research in progress at various centres. The morning of the third day was given over to research reports on now insecticides, fungicides and acaricides, and on novel formulations as well as new methods of application. In the final session attention was appropriately directed to the problems involved in translating research into practice and in introducing insecticides and fungicides into agricultural practice both in Britain and overseas. In all, more than fifty papers or reports were presented from the research departments of official agricultural institutes and industrial firms, including a number from Holland, Germany and Italy.

On introducing the president, Mr. H. C. Mellor, the chairman of the Manufacturers' Association and of the conference, said that the industry is at present under fire, though much of the criticism levelled at it is uninformed. The members of his Association are as anxious as anyone to find safer chemicals, and are most careful to honour the agreements made on their behalf with the Ministry of Agriculture, as well as to satisfy the requirements of the Notification Scheme under which all new chemicals are notified to the Ministry for clearance before marketing.

In his opening address Dr. Sanders referred to the increasingly important part played by chemicals in farming. Unfortunately, some of them are toxic to mammals and wild-life, and this has led to alarm in the public mind. He believed that much of this concern is due to ignorance of the many hurdles new chemicals have to surmount before they are cleared for marketing by Government departments of health and agriculture. The present conference was mainly a scientific one, but the delegates included meny whose functions were to translate science into practice, and it should therefore provide a good opportunity for getting things, including toxic hazards, into proper perspective. Dr. Sanders also commented on the close co-operation now existing between industry, research workers and Government officials, and expressed appreciation to the manufacturers for disclosing to him highly confidential information which has fully satisfied him that during the past five years there has been a very substantial reduction in the acreage sprayed with the more toxic chemicals, even though the total acreage sprayed has doubled during that period.

The first session was concerned with soil pests and diseases of agricultural crops, and included a review by Dr. Hubert Martin (until recently director of the Pesticide Research Institute, London, Ontario) of a symposium called privately, in February 1961, to discuss the effects of chlorinated hydrocarbons and other chemicals on the ecology of the soil fauna and flora. Dealing with the eelworm problem, $\mathbf{M r}$. F. G. W. Jones (Rothamsted Fxperimental Station) said that a first-class soil nematicide is still awaited. Only three-bromomethane, dibronioethane and dichloropropene-have stood the test of time, though some dithiocarbamates show promise. $\mathrm{He}$ doubted whether soil treatments were the right approach. Apart from difficulties of mixing and dispersion, at least 1,000 tons of soil per acre has to be treated. Eradication of eelworms is impossible and unnecessary, and he looked forward to a systemic nematicide moving from foliage to roots, suppressing the cyst-hatching factor, and perhaps passing out into the soil to exert a repellant effect. Dr. Mary Noble (Department of Agriculture for Scotland) considered that seed is not the best launching vehicle for a chemical intended to control soil-borne fungus diseases, while Mr. M. J. Way (Imperial College of Science and Technology) did much to restore a balance in the campaign against insecticidal seed dressings by insisting that the minute quantities used are effective and well placed and do not cause offflavours in crops, injure beneficial insects or encourage resistance in the pests attacked. The problem of deaths of birds after eating dressed seed should be met by more circumspect use of seed dressings and not by restrictive legislation, a view that received much support.

The use of systemic insecticides for virus control in potatoes and sugar beet was considered at a second session. Hitherto, potato virus diseases have been controlled through crop certification schemes, a method that has become traditional. Dr. L. Broadbent (Glasshouse Crops Research Institute) and others have shown that similar ends may be achieved by using systemic insecticides, though fow farmers have yet attempted to take advantage of this. With sugar beet thore has been no tradition of certification. and farmers responded quickly to a spray-warning scheme begun in 1957 to deal with virus yellows. Dr. R. Hull 